\title{
ANALISIS KARAKTERISTIK KOMEDI PADA KUIS WAKTU INDONESIA BERCANDA NET-TV
}

\author{
Freddy Yusanto, Velinda Cahyanisa \\ Program Studi Ilmu Komunikasi Universitas Telkom Bandung \\ fredyusanto@gmail.com,
}

\begin{abstract}
The lies spread by the media has been packaged to resemble the real facts, which means that the technological sophistication makes a few journalists present news and false information to the public. Attempts to package an information media in such a way as to influence public opinion. Therefore, this research focuses on the content of the program commodification Metro TV that talk about Two Sides. This program is taken considering Rating Share for considering this program menggantikian Mata Najwa considerable interest. Controversy arose because of false news which is currently traded for growing seeds of hatred. So that this research approach using narrative approach to determine the content of manufacturing in practice the contents commodification talk about Two Sides Metro TV.
\end{abstract}

Keywords: narrative talkshow, komodofikasi content, talkshow program.

\section{A. Pendahuluan}

Srimulat adalah salah satu ikon komedi di Indonesia yang muncul di pertengahan era 1980-1990. Srimulat terkenal dengan gaya lawakanslapstic, dengan menonjolkan karakter khas masing-masing pemain. Lawakan dengan gaya ini cukup mudah diterima oleh penonton karena kelucuan yang ditampilkan mudah dipahami. Namun gaya lawakan slapstic seperti ini kurang memberikan edukasi kepada penonton. Konsep program komedi pun terus mengalami perubahan, dari sederhana hingga yang kompleks. Tahun 80an, program komedi masih diposisikan sebagai konten 'intermezzo' dalam sebuah program. Salah satu program acara pada saat itu adalah Aneka Ria Safari, yang ditayangkan di awal tahun 80an.

Program Variety Show ini adalah program musik yang menampilkan musikmusik Indonesia saat itu, namun dalam setiap episodenya, konten lawakan selalu dimunculkan sebagai penyegar dalam program ini. Konten komedi saat itu dibawakan oleh grup lawak seperti Jayakarta Grup (Cahyono, Jojon, Prapto dan Uuk), Bagio CS, D' Bodors. Kwartet Jaya dll. Kemudian mulai bermunculan program televisi khusus komedi, seperti Ria Jenaka dengan menampilkan karakter tokoh punokawan (Semar, 
Bagong, Petruk dan Gareng). Awal tahun 90an, mulai banyak program televisi komedi yang mulai bermunculan, seperti Lenong Bocah yang ditayangkan di TPI (sekarang MNC TV), Grup lawak Bagito dengan program 'Bagito Show' yang ditayangkan di RCTI, Patrio dengan program 'Ngelaba' ditayangkan di TPI, Aneka Ria Srimulat, tayang di Indosiar.Memasuki awal tahun 2000, program komedi masih didominasi oleh grup lawak seperti grup Cagur dengan program 'Chatting' yang ditayangkan di TPI, Ngelenong Nyook yang ditayangkan di Trans TV, Extravaganza yang ditayangkan di Trans TV, serta Opera Van Java yang ditayangkan di Trans 7.

Tahun 2000-an, konsep alur cerita masih sama, menceritakan tentang kondisi keseharian masyarakat kita. Program komedi yang cukup popular di tahun 2010 hingga tahun 2018 ini diantaranya Pesbukers, Opera Van Java, Waktu Indonesia Bercanda (WIB), Waktu Indoensia Timur (WIT) dll. Jika dilihat dari sisi visual, dari tahun 80-hingga tahun 2010-an, terlihat perubahan yang cukup significat, terutama bagian setting dan property yang digunakan.

Program komedi Waktu Indonesia Bercanda (WIB) adalah salah satu program komedi yang menampilkan konsep komedi yang berbeda secara konten. Dengan 'meminjam' genre program kuis, WIB dikemas dengan memasukkan unsur-unsur program kuis seperti tebak kata, Teka-Teki Silang (yang diplesetkan menjadi TekaTeki Sulit), tebak gambar dll. Sebenarnya teknik penciptaan humor cukup beragam. Kadang kala penonton tidak menyadari, mengapa sebuah komedi itu lucu, namun penonton dibuat tertawa, itulah teknik humor (Berger, 2012).

Tahun 2016 di bulan April, Waktu Indonesia Bercanda (WIB) tayang perdana di NET. Awalnya, program komedi ini menampilkan pembahasan yang berhubungan dengan kehidupan manusia, seperti layaknya sebuah acara motivasi (Contoh: Mario Teguh), akan tetapi seiring berjalannya waktu, acara ini kemudian mengalami perubahan konsep menjadi kuis. Konsep Kuis dalam program WIB secara visual tidak berbeda dengan acara kuis lainnya, seperti tata panggung menggunakan mimbar, pembawa acara memberikan pertanyaan kemudian peserta menjawab. Namun, program WIB menyajikan pertanyaan-pertanyaan dengan jawaban di luar logika berpikir normal, karna jawaban yang diharapkan adalah bukan jawaban sebagaimana mestinya. 
Analisa penelitian ini berdasarkan pada teori humor dari Arthur Asa Berger. Kategori humor menurut Berger terdiri atas Language (The Humor is Verbal), Logic (The Humor is Ideational), Identity (The Humor is Existenstial) dan Action (The Humor is Physical or Nonverbal), dimana masing-masing kategori memiliki dimensinya masing-masing. Korelasi humor yang dikemas dalam konsep kuis yang ditampilkan dengan pola pikir atau logika yang tidak biasa menjadi andalan kelucuan dalam obyek penelitian ini.

Program komedi masuk dalam program Non Drama. Non Drama sendiri adalah sebuah format acara televisi yang diproduksi dan dicipta secara faktual, dan mempunyai unsur yang kreatif dan juga menghibur, tetapi program Non Drama memiliki serangkaian pertunjukan yang jauh dari ‘khayalan' (Yusanto, 2016: 35).

Tabel 1. Karakter Program TV

\begin{tabular}{|l|l|}
\multicolumn{1}{|c|}{$\begin{array}{c}\text { ARTISTIK } \\
\text { (DRAMA \& NON DRAMA) }\end{array}$} & \multicolumn{1}{c|}{$\begin{array}{c}\text { JURNALISTIK } \\
\text { (HARD NEWS \& SOFT NEWS) }\end{array}$} \\
\hline Sumber : ide/ gagasan & Sumber: permasalahan \\
\hline Keindahan & Aktual \\
\hline Fiksi/ non fiksi & Realitas \\
\hline Isi pesan bisa fiksi, non fiksi/ faktual & Isi pesan harus faktual \\
\hline Tidak terikat waktu & Penyajian terikat waktu \\
\hline Sasaran kepuasan khalayak & Sasaran kepercayaan \& kepuasan khalayak \\
\hline Memenuhi rasa kagum & Memenuhi rasa ingin tahu khalayak \\
\hline Improvisasi tak terbatas & Improvisasi terbatas \\
\hline Isi pesan terikat pada kode moral & Isi pesan terikat pada kode etik jurnalistik \\
\hline Penggunaan bahasa bebas & Menggunakan bahasa jurnalistik \\
\hline Daya khayal kuat & Refleksi penyajian kuat \\
\hline Isi pesan tentang realitas sosial & Isi pesan menyerap realitas faktual \\
\hline
\end{tabular}

Sumber: Yusanto, 2016: 35

Menurut Rustono, Humor dapat menjadikan khalayak dapat merasakan humor tersebut atau tertawa apabila mengandung dari beberapa unsur seperti embarrassment (memalukan), surprise (kejutan), irrationality (irasional atau tidak masuk akal), dan hyperbolic (hiperbola).

(sumber:http://salmanaditya.com/2013/02/komedi-dan-berbagaijenisnya/diakses 05 Mei 2018 14:03 WIB). 
Tabel 2. Jenis-jenis Komedi

\begin{tabular}{|c|c|}
\hline Jenis & Pengertian \\
\hline Slapstick/Physicalcomedy & Komedi fisik yang berunsur derita, celaka dan aniaya. \\
\hline Komedi Alternatif & $\begin{array}{l}\text { Penyampaian komedi yang sedikit berbeda dari humor yang ada } \\
\text { pada era tertentu. }\end{array}$ \\
\hline Komedi Observasi & Berdasarkan dari kehidupan sehari-hari. \\
\hline Komedi Hitam & $\begin{array}{l}\text { Sisi gelap kehidupan sehari-hari seperti kejadian aktual dunia } \\
\text { politik, hiburan, olahraga, rasisme, agama dll. }\end{array}$ \\
\hline Komedi Biru & $\begin{array}{l}\text { Komedi yang didasari dari pencarian sisi biru kehidupan sehari- } \\
\text { hari dan biasanya berbau sensual. }\end{array}$ \\
\hline Komedi Karakter & Keunikan ekspresi komedian. \\
\hline Komedi Cringe & Komedi yang berasal dari kejadian canggung dan memalukan. \\
\hline Komedi Hina & $\begin{array}{l}\text { Memfokuskan subjeknya dengan cara menghina atau merendahkan } \\
\text { orang lain. }\end{array}$ \\
\hline Komedi Properti & $\begin{array}{l}\text { Mengandalkan atau menggunakan properti dalam menampilkan } \\
\text { aksi humor atau kelucuan. }\end{array}$ \\
\hline Komedi Tidak Nyata & $\begin{array}{l}\text { Komedi yang pada dasarnya terbuat dari sesuatu yang tidak nyata, } \\
\text { atau tidak masuk akal dan aneh. }\end{array}$ \\
\hline Komedi Sketsa & $\begin{array}{l}\text { Memiliki skema terstruktur. Durasi antara } 1 \_10 \text { menit dengan } \\
\text { pertunjukan sebuah kejadian atau tingkah yang membuat terkejut. }\end{array}$ \\
\hline
\end{tabular}

Sumber :http://salmanaditya.com

Humor adalah subjek yang mengundang perhatian dan ketertarikan, karena setiap humor memiliki teknik yang bisa menghasilkan suatu kekocakan (Berger, 2012). Adapun teknik-teknik humor menurut Arthur Asa Berger berdasarkan kategori humor, yakni: 1) Language (The Humor is verbal, 2) Logic, The humor is Ideational, 3) Identity. The Humor isExistensial, 4) Action. The Humor is Physicalor Nonverbal.

1. Language (The Humor is verbal). Humor merupakan sesuatu yang berasal dari makna kata. Cara berbicara atau akibat dari pembicaraan. Berger membagi kategori ini menjadi beberapa teknik: a) Bombast; b) Definition; c) Irony; d) Misunderstanding; e) Puns; f) Repartee; g) Ridicule; h) Sarcasm; i) Satire; j) Sexualallusion; k) Infanitilism; l) Exaggeration; m) Outwitting;

2. Logic, The humor is Ideational. Humor diciptakan melalui suatu ide atau hasil dari pemikiran. Berikut Berger membagi kategori menjadi beberapa teknik, yakni: a) Absurdity; b)Coincidence; c)Dissapointment; d)Repetition; e)Rigidity; f) Ignorance. 
3. Identity. The Humor isExistensial. Dalam kategori ini, humor muncul melalui identitas atau karakter pemain. Berikut beberapa teknik dalam kategori ini yang dibagi oleh Berger; a) Eccentricit; b) Imitatio; c) Grotesque appereance; d) Parod; e) Anthropomorphism; h) Stereotype; i) Visual surprise; j) Embarrasment; k) Impersonate:

4. Action. The Humor is Physicalor Nonverbal. Pada kategori ini humor muncul dari tindakan fisik/ komunikasi nonverbal seperti halnya pergerakan tangan, kaki atau suatu aksi dan ekspresi. Berger membagi kategori ini menjadi beberapa bagian: a) Slapstick; b) Speed; c) Chase.

\section{B. Hasil dan Pembahasan}

\section{Kategori Language (The Humor is Verbal)}

Kategori language memiliki 13 dimensi, salah satunya Dimensi Misunderstanding (kesalahpahaman). Teknik pemakaian bahasa sebagai media humor yang digunakan oleh para komedian adalah teknik mengecoh, teknik ejekan, teknik kesalahpahaman dan teknik permainan bunyi. Berikut adalah percakapan saat menggunakan teknik misunderstanding (kesalahpahaman):

WIB/31 Juli 2018/TTS

Cak Lontong : : "Delapan kotak mendatar. Yang mendorong atlet saat bertanding supaya semangat... Ada huruf 'R' di kotak kelima”

Kang Deni : "Luar ring dah kayanya, kan nggak mungkin banget supporter.

Pepi : "Ntar dulu!"

Cak Lontong : "Yak apakah 'ntar dulu'?

Percakapan antara Pepi dan Cak Lontong mengalami kesalahpahaman. Kalimat yang mengggunakan nada penekanan sengaja dianggap sebagai jawaban dari pertanyaan tersebut oleh Cak Lontong pada saat itu untuk dimasukkan ke dalam kotak. Dalam humor, teknik kesalahpahaman sering disengaja dilakukan untuk memicu efek kelucuan.

\section{Penciptaan Humor Teknik Language dengan Dimensi Outwitting}

Dimensi Outwitting dibuat untuk mengukur atau disengaja untuk memicu terjadinya perdebatan.

WIB/28 Agustus 2018/TTS 


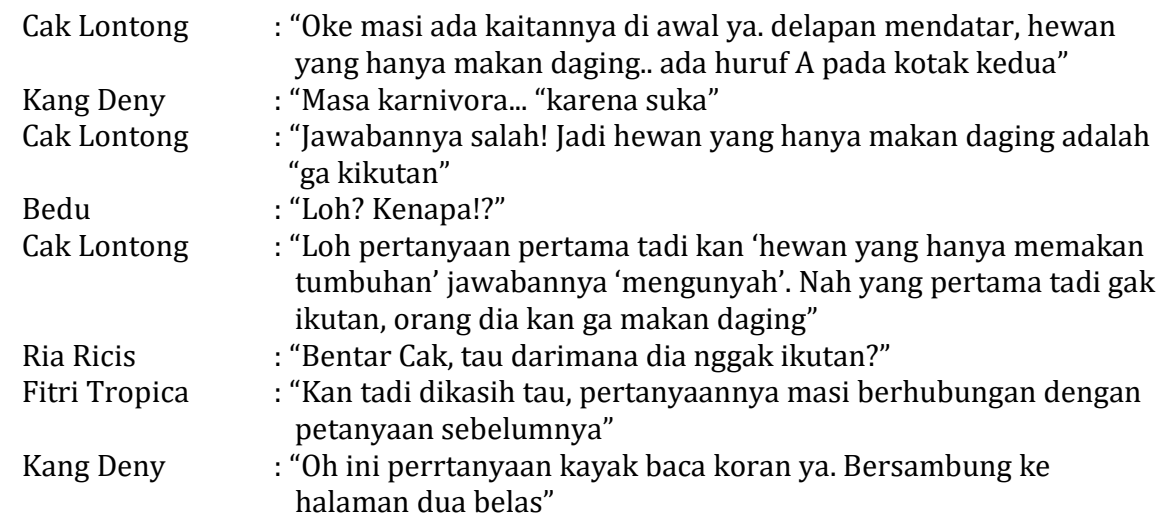

Sebelumnya Cak Lontong memberikan pertanyaan dimana 'hewan yang hanya makan tumbuhan' jawabannya 'mengunyah'. Kemudian pada pertanyaan kedua Cak Lontong memberikan pertanyaan 'hewan yang hanya makan daging', pertanyaan tersebut secara umum akan dijawab sejenis 'karnivora'. Terdapat pula jawaban yang dicoba oleh peserta adalah jawaban yang tidak biasa seperti hal yang selalu dilakukan dalam TTS. Akan tetapi Cak Lontong tidak memberikan jawaban sesuai dengan sudut pandang peserta.

\section{Penciptaan Humor Teknik Language dengan Dimensi Bombast}

Dimensi Bombast, diartikan sebagai dimensi omong kosong. Teknik penciptaan humor ini muncul saat seseorang membuat suatu omong kosong atau membuat suatu alasan untuk meninggi.

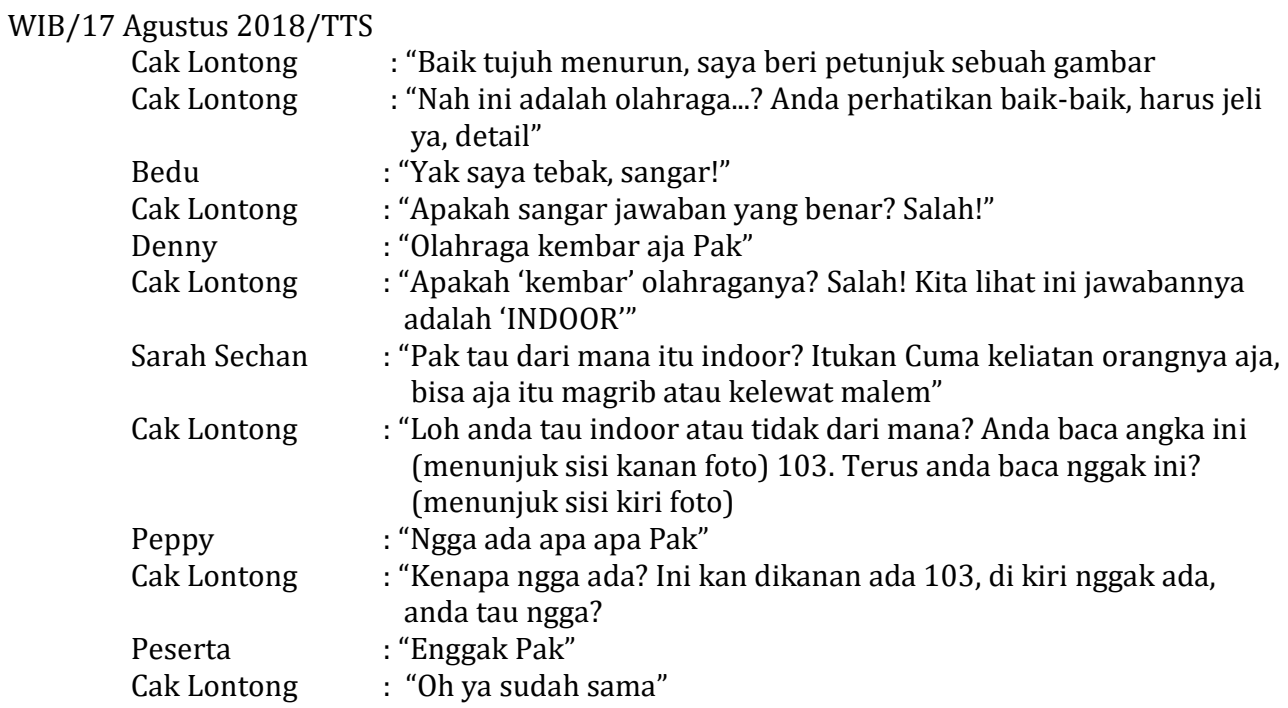


Surya Insom : : "Apa sih Pak"

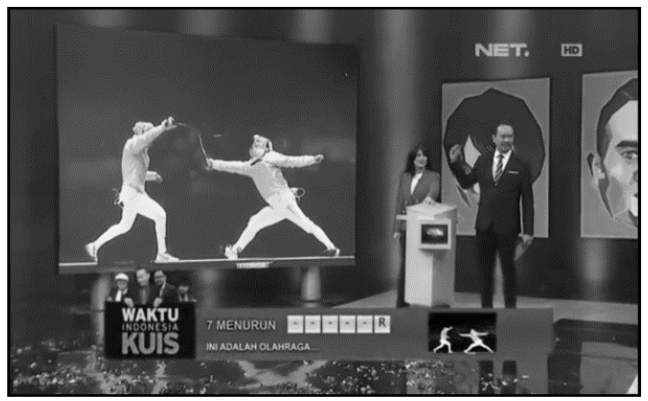

sumber : https://youtu.be/Vml8R3x98j8

\section{Gambar 1. Petunjuk soal Teka Teki Sulit WIB}

Pada percakapan diatas terjadi protes oleh peserta atas ketidak terimaan mereka pada jawaban. Cak Lontong sebagai motivator dalam kuis merasa harus bisa memberikan suatu pertanggung jawaban atau alasan terhadap jawaban. Namun yang terjadi, Cak Lontong justru bertanya-tanya seolah ingin menjelaskan sesuatu, yang pada dasarnya itu hanya omong kosong tak berujung solusi, demi bisa membalas pertanyaan yang dilontarkan peserta.

\section{Penciptaan Humor Teknik Language dengan Dimensi Definition}

Teknik penciptaan ini muncul karena humor yang dilontarkan oleh pelawak tidak sesuai harapan dan tidak dapat ditangkap oleh penonton.

WIB/ 17 Agustus 2018/TTS

Cak Lontong

Insan Nur Akbar

Cak Lontong

Surya Insomnia
: "Jawaban yang benar adalah 'busana"”

: "Pak, harusnya dia bener dong, kan jawabannya dia celana. Celana kan busana, dan dimanfaatkan untuk sabuk Pak"

: "Hey, celana sama busana mungkin ada miripnya. Tapikan itu untuk daerah tertentu, Jawa Barat, sunda gitu kan. (Lalu peserta sejenak terdiam, menelaah apa yang dikatakan oleh Cak Lontong)

: "Yaampun ih Pak. Bukan 'eceu"'

Percakapan diatas sempat terjadi momen diam, karna belum mengerti apa yang dimaksudkan oleh lawakan yang dilontarkan oleh Cak Lontong. Namun setelah peserta mengerti apa yang dimaksudkan oleh Cak Lontong, barulah humor tersebut tersampaikan. 


\section{Penciptaan Humor Teknik Language dengan Dimensi Puns}

Dimensi ini berada pada ranah permainan makna kata, seperti halnya membolak balikkan kata, sehingga terdengar lucu ketika diucapkan.

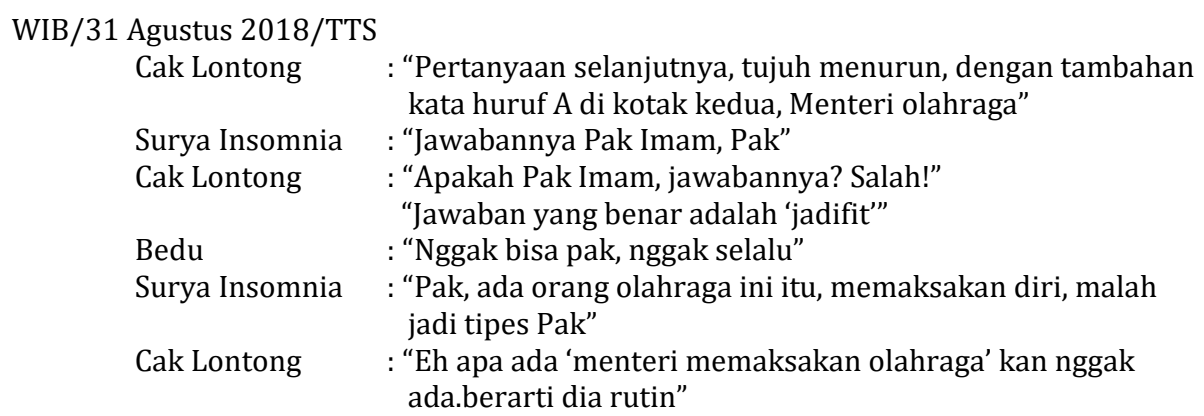

Dimensi satire ini hampir setiap pertanyaannya selalu digunakan. Karena konsep pertanyaan dari WIB adalah permainan kata, atau penyusunan kata yang dibuat sedemikian rupa agar memiliki kemajemukan asumsi. Contohnya percakapan diatas, dimana pertanyaannya adalah "mentri olahraga". Dalam pertanyaan tersebut, pembuat soal tidak meletakkan kata "siapa", atau kata "adalah", sehingga pembuat soal sengaja tidak meletakkan asumsi "subjek" pada pertanyaan. Jadi pemain harus sangat kritis pada permainan kata yang dibuat oleh pembuat soal.

\section{Penciptaan Humor Teknik Language dengan Dimensi Satire}

Dimensi ini muncul karna telah membuat orang terlihat bodoh atau mempermalukan suatu hal, situasi, atau tokoh masyarakat.

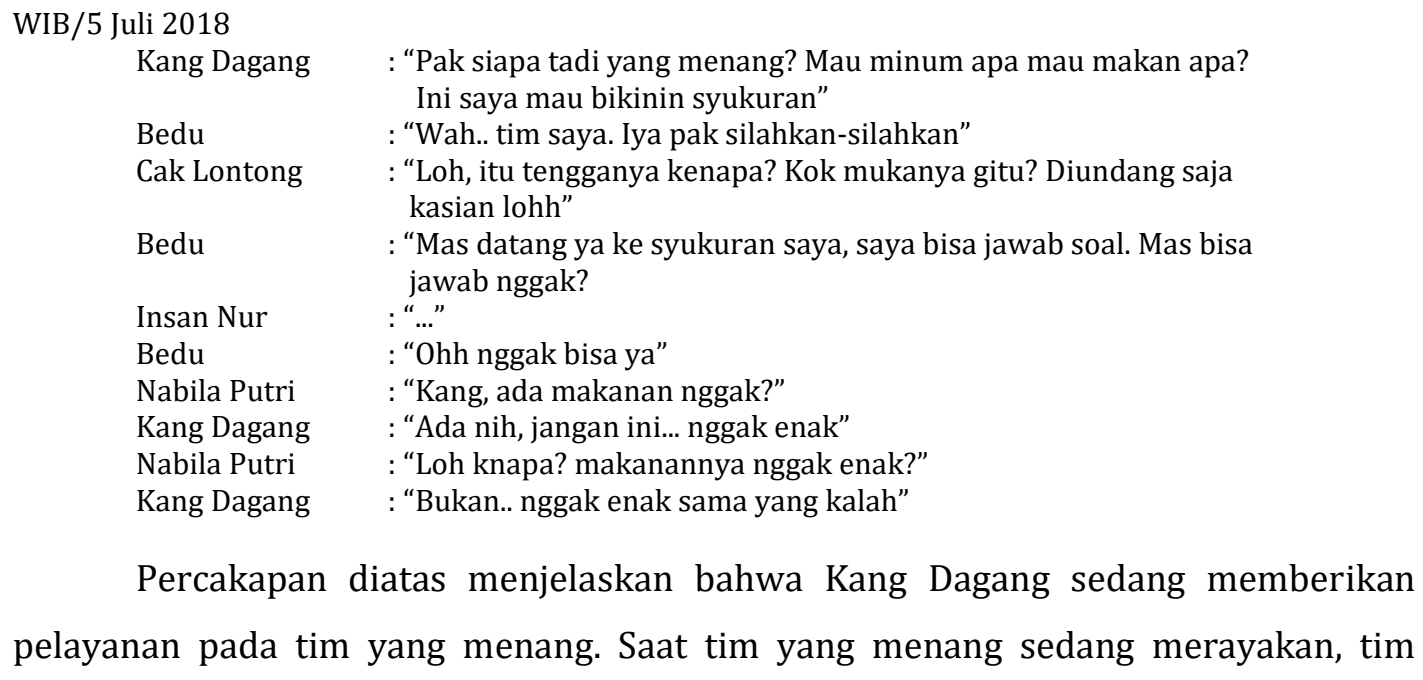

Percakapan diatas menjelaskan bahwa Kang Dagang sedang memberikan pelayanan pada tim yang menang. Saat tim yang menang sedang merayakan, tim 
kalah pun hanya berdiri terdiam dan Cak Lontong menanyakan "kenapa mukanya begitu", dimana ia berniat untuk menyindir pemain yang tidak berhasil menjawab dan telah kalah.

\section{Penciptaan Humor Teknik Language dengan Dimensi Irony}

Teknik Irony atau ejekan ini, humor tercipta karna ejekan atau celaan yang dilakukan secara langsung.

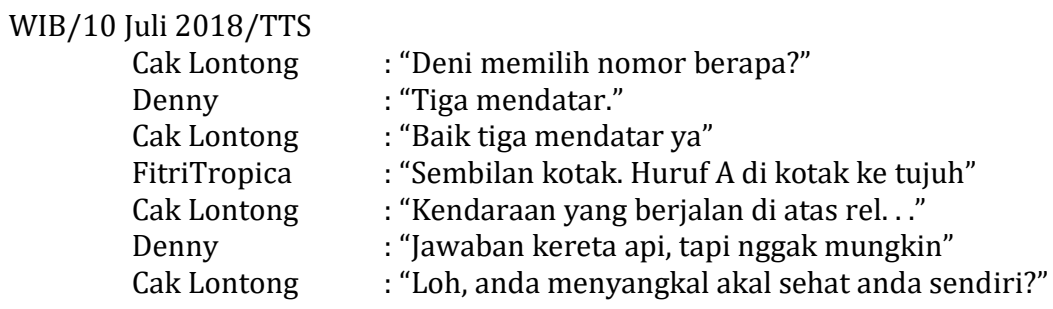

Percakapan barusan adalah salah satu contoh ejekan secara langsung yang diberikan Cak Lontong kepada Kang Denny. Ejekan yang diberikan diakibatkan karna ucapan Denny yang terbilang aneh untuk didengar. Namun ucapan itu sendiripun keluar karna rasa tidak percaya diri Denny dalam menjawab pertanyaan, yang kemudian langsung dijadikan momentum untuk memunculkan efek humor oleh Cak Lontong dengan cara mencela peserta dengan secara halus namun tepat pada sasaran.

\section{Kategori Logic (The Humor is Ideational)}

Menurut Berger, kategori ini adalah ide penciptaan humor melalui permainan logika, kelucuan akan muncul secara tidak terduga.

\section{Penciptaan Humor Teknik Logic dengan Dimensi Dissapointment}

Kekecewaan memiliki dua jenis, pertama kekecewaan bodoh, yang berarti kekecewaan itu sesungguhnya tidak perlu terjadi, sebab utamanya adalah keinginan yang mustahil atau impian di siang bolong. Kedua kekecewaan sehat, dimana kekecewaan yang dirasakan ketika suatu keadilan sedang tidak berpihak atau kerja keras disepelekan. Dimensi ini terjadi karna adanya rasa kecewa atau karna adanya suatu hal yang tidak sesuai dengan harapan.

WIB/27 Juli 2018/TTS 


\begin{tabular}{|c|c|}
\hline Cak Lontong & $\begin{array}{l}\text { : Baik pertanyaan pertama untuk tim A, di tujuh mendatar dengan } \\
\text { bantuan huruf A pada kotak ke enam. pilot, taupilotkan? Nah pilot } \\
\text { adalah orang yang mengemudikan }\end{array}$ \\
\hline Nikita Mirzani & : Pesawat... eh bukan bukan.... salah \\
\hline Bedu & : Dua tangan \\
\hline Cak Lontong & : Pilot adalah yang mengemudikan.. dua tangan. Kita lihat.. salah. \\
\hline Fitri Tropica & : Ayok tim B saatnya menjawab \\
\hline Arie Kriting & : Kenalan Pak. Kan sebelum ngemudiin kenalan dulu \\
\hline Cak Lontong & $\begin{array}{l}\text { : Kenalan? Kita lihat. Salah juga. Kita lihat.. ini dia jawaban yang } \\
\text { dimaksud. DIDEPAN }\end{array}$ \\
\hline Arie Kriting & : "Semua orang juga tau pilot itu di depan Pak. \\
\hline Cak Lontong & : “Loh ga semua orang tau. Kalian nggak tau. Kan salah tadi. \\
\hline Nikita Mirzani & $\begin{array}{l}\text { : "Eh tapikan yang didepan itu ada yang dipinggir, mana kanan apa } \\
\text { kiri? Gak ada depan itu dimana, yang spesifik dong. Didepan kaca? } \\
\text { Di depan mana? Yang spesifik dong!" }\end{array}$ \\
\hline
\end{tabular}

Pertanyaan ini pastinya akan dijawab oleh orang awam dengan jawaban "pesawat", namun kembali lagi, WIB adalah kuis yang dibuat dengan logika berpikir bebas. Pada percakapan diatas, Nikita mengeluarkan rasa kekesalannya dengan cara nada meninggi dan balik bertanya pada Cak Lontong secara spesifik. Namun dari kekesalan Nikita, justru menjadi suatu humor dengan memperpanjang, atau membahas apa yang ditanyakan balik oleh Nikita pada Cak Lontong.

\section{Penciptaan Humor Teknik Logic dengan Dimensi Absurdity}

Di dalam penciptaan humor, kemustahilan selalu dibenturkan antara pemahaman orang tentangkenyataan dengan suatu pemaksaan dari pembuat humor, bahwa segala yang ia ucapkan mungkin saja terjadi, dengan diikuti alasan-alasan aneh yang bermaksud untuk menimbulkan kelucuan. Dimensi ini adalah saat pemain menunjukkan sikap yang tak masuk akal atau atau menunjukkan suatu sikap karena hal yang mustahil.

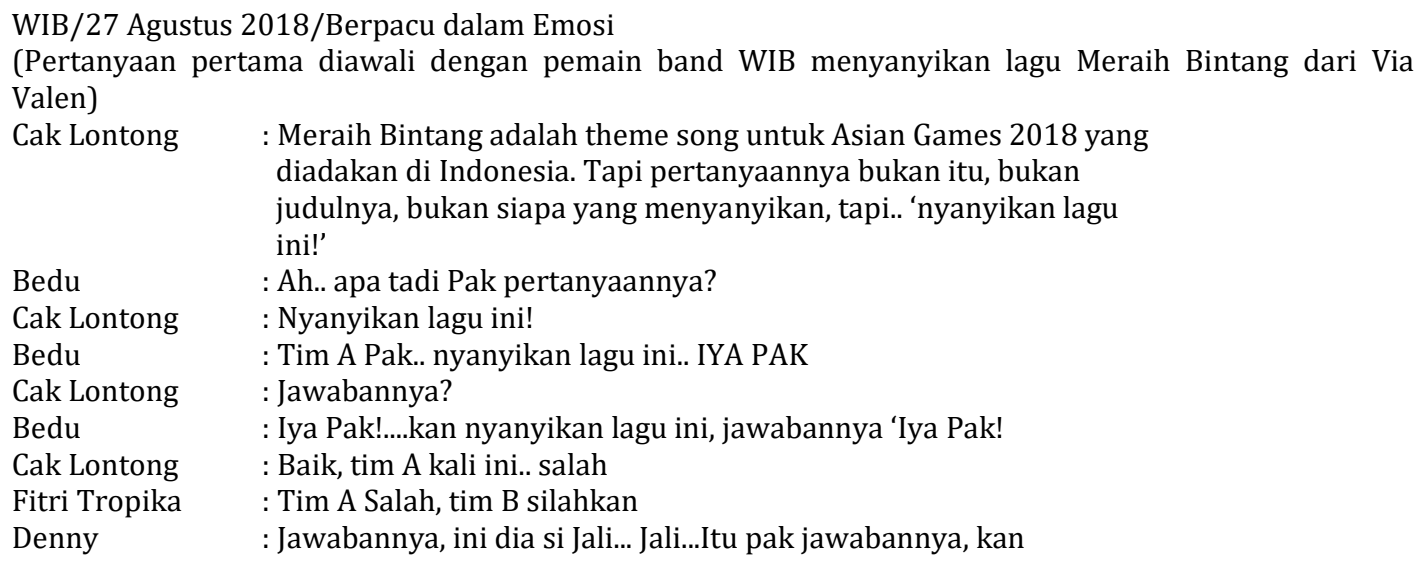




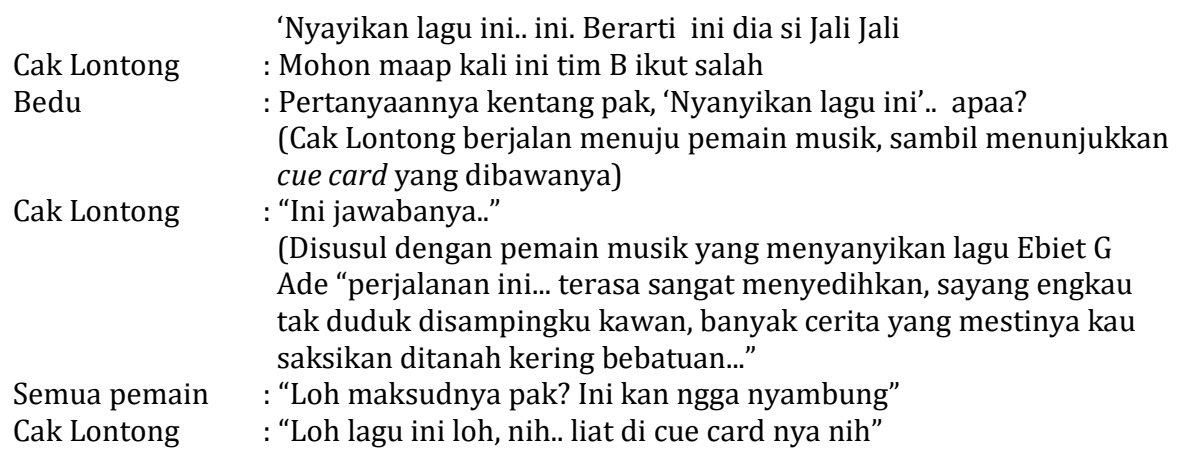

Pada percakapan ini, pertanyaan pertama diawali dengan lagu Meraih Bintang, tetapi Cak Lontong mengatakan bahwa pertanyaan ini tidak ada kaitannya dengan lagu tersebut. Kemudian Cak Lontong memberi suatu pertanyaan yang mengganjal, peserta pun memiliki ekspetasi jawaban, namun pada WIB jawaban dengan logika bebas. Setelah semua peserta sudah salah menjawab, maka Cak Lontong memberikan jawabannya pada pemain musik, dan justru yang dimainkan adalah lagu dari Ebiet G. Ade. Hal tersebut membuat peserta bertanya-tanya, "mengapa jawabannya itu". Yang terjadi adalah, Cak Lontong memberikan perintah pertama, namun judul yang harus dinyanyikan tidak diberitahukan kepada peserta, melainkan hanya dipegang oleh nya. Saat disalahkan oleh peserta, Cak Lontong pun menyangkal bahwa ia tidak bersalah, karena "ini" yang dimaksud dalam pertanyaan "nyanyikan lagu ini" berada pada cue card yang tidak ditunjukkan pada peserta, namun hanya dihadapkan pada nya. Maka hal ini membuat suatu kemustahilan untuk peserta dapat menjawab pertanyaan atau perintah yang diberikan dengan benar.

\section{Kategori Identity (The Humor is Existensial)}

Menurut Berger, kategori Identity atau bentuk adalah aspek humor yang dalam ide ini, suatu peristiwa atau gagasan dilebih-lebihkan dengan cara yang tidak setara hingga menimbulkan suatu keanehan atau keganjilan dan terkadang humor ini terjadi melalui adanya identitas dari pemain, contohnya saja penampilan dari pemain yang menyerupai suatu atau seorang karakter. Pada kategori Identity, WIB banyak menggunakan dimensi Impersonate, dan Imitation. 


\section{Penciptaan Humor Teknik Identity Dengan Dimensi Impersonate}

Dimensi ini sebagai teknik peniruan tokoh, baik itu gaya bicara, gerak tubuh atau kata-kata khasnya.

WIB/20 Agustus 2018

$\begin{array}{ll}\text { Nabila Putri } & \text { : Karna hari ini ada Vega, dan dia baru pertama bermain } \\ \text { Vega } & \text { : Bener, baru. Nggak liat apa masih diplastikin } \\ \text { Cak Lontong } & \text { : Saya akan membacakan rule rule rule (sambil memajukan bibir, } \\ & \text { dengan tangan seolah akan mencabut bibir). Baik, }\end{array}$

Diketahui dahulu Vega Darmayanti adalah co-host Tukul Arwana. Maka dalam percakapan diatas, Cak Lontong menirukan tingkah laku atau ciri khas terkenal yang sering dilakukan oleh Tukul Arwana. Seperti halnya berbicra, sambil menggerakan tangan seolah akan mencabut bibir, dan teriakan 'ea ea' pada gerakan tangannya. Halhal yang ditirukan oleh Cak Lontong tersebut mengundang tawa.

\section{Penciptaan humor teknik Identity dengan dimensi Imitation}

Imitation sama dengan menirukan. Berbeda dengan teknik peniruan yang sebelumnya, jika impersonate adalah menirukan gaya khas dari suatu karakter atau tokoh, sedangkan imitasi menirukan identitas atau suatu peran. Dalam dimensi ini tercipta karena adanya pemain yang mengambil identitas orang lain, baik itu disengaja maupun tidak.

WIB/5 Juli 2018/TTS

$\begin{array}{ll}\text { Cak Lontong } & \text { : Tiga mendatar, enam kotak dengan huruf bantuan A pada kotak ke } \\ & \text { lima. Pertanyaannya, orang hamil biasanya } \\ \text { Insan Nur } & \text { : Orang hamil biasanya, 'mengusap' Pak }\end{array}$

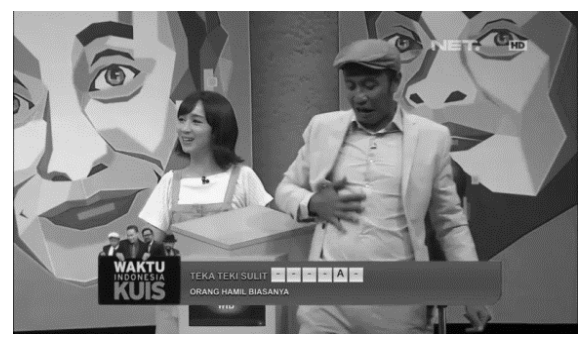

Sumber : $\underline{\text { https://www.youtube.com }}$

\section{Gambar 2. Dimensi Imitasi yang Dilakukan Pemain}

Percakapan tersebut, Insan menjawab 'mengusap', saat ia menjawab hal tersebut, ia sambil memperagakan keadaan ibu hamil yang sedang berjalan, yakni 
dengan membusungkan perut kedepan, berjalan dengan lambat, dan satu tangan mengusap perut seperti gambar di atas. Jadi ia memposisikan diri sebagai ibu hamil, disitulah dimensi imitasi digunakan, guna menciptakan suatu humor.

\section{Kategori Action (The Humor is Physical or Nonverbal)}

Kategori ini muncul dari adanya tindakan fisik atau komunikasi nonverbal yang terjadi, seperti halnya pergerakan tangan, kaki atau suatu ekspresi berupa aksi. Adapun dimensi yang sering terjadi pada WIB hanyalah speed.

\section{Penciptaan Humor Teknik Action Dengan Dimensi Speed}

Teknik ini dilakukan dengan cara seolah-olah penonton tengah menekan tombol rewind televisi sehingga muncul adegan seperti gerakan yang dipercepat. Dimensi ini terjadi karna adanya pemain yang berbicara cepat atau bergerak dengan sangat cepat atau sangat lambat.

WIB/31 Agustus 2018/TTS

$\begin{array}{ll}\text { Cak Lontong } & \text { : Nama olahraga yang tidak menggunakan bola..Jawabannya adalah } \\ & \text { 'sepak', kan 'nama' olahraga yang nggak pake bola } \\ \text { Denny } & \text { : Eh, sejak kapan ada olahraga sepak!? } \\ \text { Bedu } & \text { Olahraga itu sepak Pak? Apakah masuk dalam cabang permainan? } \\ & \text { Cabang olahraga atletik? Atau cabang olahraga pembantu!? Berarti } \\ & \text { bukan olahraga pak kalo Cuma sepak-sepak doang! Kayak bulu } \\ & \text { tangkis, trus nggakpake tangkis, jadi bulu doang!? Trus mainin } \\ & \text { bulu aja nggak ditangkis-tangkis. Nggak bisa Pak! Namanya } \\ & \text { olahraga itu menjadi satu kesatuan. Trus bagaimana kalo makan } \\ & \text { tongseng? Bapak pernah makan tong!? Nggak pake seng!? }\end{array}$

Apa yang dikatakan Bedu adalah suatu dimensi humor satire. Karna pada percakapan diatas Bedu meluapkan emosinya dengan cara protes dengan nada bicara meninggi dan cepat, tidak terputus kalimatnya. Sembari ia mengatakan rasa protesnya, Bedu juga sambil mempraktikkan setiap kata yang ia katakan, (melakukan gaya bahasa nonverbal). Tentunya hal tersebut mengundang tawa baik itu penonton maupun pemain, karena segala yang diucap, didukung oleh kecepatan berbicara dan gesture tangan maupun badan yang ikut berbicara. 


\section{PERSERPSI}

Volume 2/Nomor1

Juli - Desember 2019

E-ISSN 2656-050X

\section{Simpulan}

Teknik humor merupakan hal penting yang digunakan dalam menganalisa suatu komedi, bahkan semua teknik yang dijelaskan dalam daftar istilah teknik humor Berger dapat ditinjau dari fungsinya. Semua dimensi humor Berger tidak digunakan dalam program kuis komedi Waktu Indonesia Bercanda. Pada 31 dimensi yang ada dalam empat kategori humor, ada tujuh belas dimensi yang biasanya digunakan oleh WIB.

Dimensi yang paling banyak digunakan oleh program komedi Waktu Indonesia Bercanda NET.TV berasal dari: Kategori language dari lima belas dimensi, WIB menggunakan sembilan dimensi yakni bombast, definition, puns, satire, innocence, irony, misunderstanding, repartee, outwitting. Kategori Logic, dari enam dimensi, WIB menggunakan dua dimensi, yakni disspaoinment dan absurdity. Kategori Identity dari sembilan dimensi, WIB menggunakan tiga dimensi, yakni impersonate dan imitation. Kategori Action dari tiga dimensi, WIB menggunakan satu dimensi yakni speed.

Dimensi yang ada pada kategori action seperti slapstik dan chase sangat jarang terjadi, bahkan dimensi slapstiktidak ada dalam program Waktu Indonesia Bercanda. Program komedi ini sangat menghindari dimensi slapstik hingga saat ini.

\section{REFERENSI}

Ali, Lukman. (1997). Kamus Besar Bahasa Indonesia. Jakarta: Balai Pustaka.

Berger, Arthur Asa. 2012. An Anatomy of Humor. United States of America: Transaction Publishers.

Mcquail, Denis. (2005). Mass Communication Theory, Fifth Edition. London: Sage Publications.

Mulyana, Deddy. (2007). Ilmu Komunikasi Suatu Pengantar. Bandung: Remaja Rosdakarya.

Mulyana, Deddy. (2018). Metodologi Penelitian Kualitatif, Paradigma Baru dalam Ilmu Komunikasi dan Ilmu Sosial Lainnya. Jakarta: Remaja Rosda Karya. 
Widjaja, A.W. 1983. Komunikasi dan Hubungan Masyarakat. Jakarta: BumiAksara.

Yusanto, Freddy, S. Sos., M.Ds., dan Esfandari, Agung Diah, B.A., M.Si. 2016. Produksi Progam Televisi. Yogyakarta: Deepublish. 